\title{
Pragmatism and Nationalism: Industrialization Policy in Indonesia and Nigeria ${ }^{2}$
}

\author{
Ahmad Helmy Fuady ${ }^{a, *}$ \\ ${ }^{a}$ Research Center for Regional Resources, Indonesian Institute of Sciences (LIPI)
}

\begin{abstract}
This paper examines industrialization policy in two oil giant economies, Indonesia and Nigeria. What are the key features of continued economic divergence in these two countries since the 1980s? It shows that Indonesia's policy-makers adopted a series of liberalization measures and switched to an export-oriented strategy to develop manufacturing industries from the mid-1980s, while Nigeria's policy-makers was reluctant to do so. This paper also seeks to understand the rationale behind the different policy choices. This paper argues that policy-makers' experience and educational background are possible explanation to the different industrialization policies in these two countries.
\end{abstract}

Keywords: Industrialization; Indonesia; Nigeria; Policy-Maker

\begin{abstract}
Abstrak
Tulisan ini mengamati kebijakan industrialisasi di dua perekonomian raksasa berbasis minyak, yaitu Indonesia dan Nigeria. Apa fitur kunci dari divergensi ekonomi berkelanjutan di kedua negara sejak 1980an? Perumus kebijakan Indonesia menerapkan upaya liberalisasi dan berubah ke strategi orientasi ekspor untuk mengembangkan industri pengolahan sejak pertengahan 1980an, sedangkan perumus kebijakan Nigeria enggan menerapkan langkah serupa. Tulisan ini berusaha memahami alasan dibalik pilihan kebijakan yang berlainan. Tulisan ini berpendapat bahwa pengalaman dan latar belakang pendidikan perumus kebijakan merupakan salah satu alternatif penjelasan atas perbedaan kebijakan industrialisasi di kedua negara.
\end{abstract}

Kata kunci: Industrialisasi; Indonesia; Nigeria; Pengambil Kebijakan

JEL classifications: B310, O250, O570

\section{Introduction}

Indonesia and Nigeria are two oil rich countries, which share similarities in many respects. Both are located in a tropical area, have very large and ethnically diverse population, experienced a long history of colonial rule, and are notorious for their high level of corruption. Both countries were ruled by military leaders from 1966 to 1998 (with two brief civilian administrations in Nigeria in 19791983 and 1993). Despite these similarities, they show a stark contrast in economic performance.

\footnotetext{
This paper is developed from my Ph.D. thesis, Elites and Economic Policies in Indonesia and Nigeria, 1966-1998, at the Universiteit van Amsterdam.

* Corresponding Address: Jend. Gatot Subroto Street No. 10, Jakarta 12710 Indonesia E-mail: elhelmy@yahoo.com.
}

In the wake of independence, in the 1960s, Nigeria was full of optimism about the future of the economy. However, like a tragedy, up to the end of the 1990 s the economy grew very slow and often grew at a negative rate, while two thirds of the population lived below the poverty line and inequality increased considerably. By contrast, after years of pessimism and chaos in the early 1960s, like a miracle, Indonesia's economy grew continuously at an average annual rate of 7 per cent and experienced rapid poverty reduction.

Industrialization has been regarded as a major factor contributing to divergent economic developments in Asia and Africa. This has also been a feature of Indonesia-Nigeria comparisons since the $1980 \mathrm{~s}^{1}$. Since the mid-1980s, the manufacturing

${ }^{1}$ In 1970 s and the beginning of the 1980 s, the key to rapid 
sector has been an engine of growth in Indonesia.The ccontribution of the sector to the country's GDP increased significantly, from 8 percent in 1965 to 29 percent in 2003 (World Bank 2007b). The value added of manufacturing in Indonesia surpassed that of the agricultural sector in 1989, and the gap between the two has grown considerably since then. In Nigeria, however, the manufacturing sector has not grown rapidly, with the value added of this sector averaging only around 5 percent of GDP from 1965 to 2003, while agriculture's value added reached 34 percent of GDP during the same period (World Bank 2007b). Moreover, Indonesia experienced a substantial transformation into an industrial economy by weaning itself away from oil dependence, while Nigeria's economy 'persisted as an oil monoculture' (Lewis 2007, p. 187).

In Indonesia and Nigeria, manufacturing performance diverged significantly starting from the early 1980s, when oil prices began to drop. Even though both countries changed their industrialization strategy during this period from an import-substitution strategy to an export-promotion strategy, there were significant differences between these two countries. In the early 1980s, Indonesia's policymakers implemented a series of economic liberalization measures. This liberalization was sustained and even increased gross capital formation in Indonesia, when the state could no longer rely on oil revenues. Nigeria's policy-makers, in contrast, failed to improve gross capital formation in the economy with their half-hearted economic reform measures. In fact, investment policies in these two economies also differed significantly during this period. During the oil boom period in the 1970s, the governments in both countries adopted nationalistic inward-looking policies, and an import-substitution strategy. After the end of the oil boom in the early 1980s, Indonesia's policy-makers clearly wanted to stimulate more domestic private investment as well as FDI. In contrast, Nigerian policy-makers were still reluctant to provide more room for private and foreign participation.

This paper aims to understand why Indonesian policy-makers opted for a switch to export-oriented

economic development and poverty alleviation in Indonesia was attributed to a pronounced rural-agricultural bias in development spending. Meanwhile, the poor economic result in Nigeria was due to neglect of the rural-agricultural sector. industrialization since the 1980s, while Nigerian policy-makers were reluctant to do so. There are several studies attempt to explain the economic divergence by examining the historical and institutional contexts in the two countries (see for instance Bevan et al. 1999; Kohli 2004; Eifert et al. 2002; Lewis 2007; and Thorbecke 1998). According to Bevan, Indonesia historically had a greater export orientation and there was more smuggling between the islands outside Java and neighbouring countries (Bevan et al. 1999, p. 419). These conditions made an outward orientation in Indonesian economic policies more acceptable to policymakers. Kohli (2004, p. 327) argues that failure in Nigeria's industrialization can be traced back to the colonial period, in which 'British "effortless" colonialism laid the foundation of a distorted state and a commodity-dependent economy'. In the postcolonial period, Nigeria has indeed been an ineffective state, characterized by a personalistic and ethnically fragmented political elite, combined with an army and bureaucrats that are not competent, and lack of long-term vision (Kohli 2004, pp. 3634). The state's ineffectiveness, lacking the vision and organizational capacity to promote industrialization, is thus argued to have contributed to Nigeria's development failures. Meanwhile, Eiffert et al. (2002), Thorbecke (1998) and Lewis (2007) emphasize how policy-makers in Nigeria were divided along communal and factional lines, and concludes that this made a problem of collective action. Moreover, patronage, clientelism, ethnic division, rent seeking, and conflict over welfare distribution led the country astray (Lewis 2007, pp. 778). Different to the previous studies, in this study shows the importance of personal background and life experience of policy-makers in shaping development in Indonesia and Nigeria, which has received very little attention in the existing literature. It argues that policy-makers' experience and educational background are possible explanation to the different industrialization policies in these two countries.

This paper first briefly presents the importance of policy-makers' backgrounds to shape their policies. It then provides an overview of industrialization policies in Indonesia and Nigeria. This paper then presents short biographies of the policy-makers responsible for the industrialization policies in the two countries, to assess the relevance of their personal background to the policies they espoused. 


\section{Analysis}

\subsection{The Importance Personal Back- ground and Life Experience}

Personal background (family, regional origins, ethnicity, religion, education, as well as political and professional affiliation) of policy-makers is important for understanding how their opinions are formed and what kinds of policies they are likely to support. There are at least two reasons. First, a policy-maker is often obligated to serve the interests of their group. This obligation usually comes from the background that provides the elite a basis for holding and maintaining their power. A policymaker drawn from a political party is required to serve the party's interests. Similarly, a policymaker who make use of class or ethnic sentiments to gain political power will need to serve their constituents. Of course, this tendency also works in the reverse direction. Educational background, for example, brings with it community networks that are important in maintaining an elite's power. This is not only in terms of alumni networks of a school, but also intellectual networks that share similar belief systems, codes of conduct and a certain established behaviour. Such an intellectual network, also known as an epistemic community, may support the elite's choices in policy-making. This epistemic community can help to provide policy arguments, not only for the policy-maker, but also for the public. This community can serve as 'guardian angels' for the elite's policy choices.

Second, personal background may shape an elite's belief in certain values and ideas that they think suit them or their society (see also Guiso, Sapienza, and Zingales 2006; Harrison 2000; and Ziegler 1995, p. 345). 'Different religious affiliations and ethnic backgrounds are associated with different preferences for redistribution [and] different preferences for redistribution affect actual redistribution' (Guiso et al. 2006, p. 24). Intellectual background, for instance, will help to explain an elite's perception of certain policy ideas, because, as Derlien (1990, p. 350) notes, 'certain types of education and training might be better suited towards devising and carrying out a specific required policy'. Those trained in a liberal economics school of thought, for instance, are more likely to prefer liberal economic policies relying on market forces rather than a regulatory economy or state interventions.

It should be realized, however, that having a certain social background is not a guarantee that an elite will act according to the interests predicted by that background. For instance, a policy-maker of rural origins will not automatically prefer ruralbiased policies. It depends on how the person perceives being of rural origin. It is possible that having childhood memories of growing up in rural areas will lead the policy-maker to prioritize development in rural areas. However, there is also the possibility that the policy-maker will perceive rural areas as 'backward', and therefore prioritize the development of 'modern' urban areas.

Examining the background of policy-makers does not imply denying their ability to change. Even though they learned attitudes about authority, development, morality and democracy in childhood, this does not mean that they cannot change. Life experience provides the possibility for policymakers to learn about the necessity of certain policy measures, about what kind of policy would be the 'right' or 'wrong' policy. A policy-maker can learn from success or failure of policies that have been implemented by themselves or by previous policy-makers. In Indonesia, experiencing the mismanaged economy in the 1950s and early 1960s, with disastrous consequences, provided important lessons for the policy-maker in Suharto's period not to commit similar mistakes. A 'shocking' experience provides a 'wake-up call' for a policymaker to be alert to possible consequences of their decision-making.

There is also an importance role of policy-makers' network. Parry (1969, p. 97) notes that the process of 'political socialization' is dynamic and therefore the outlook of members of an elite can change fundamentally during their careers. Close encounters with business professionals and international donors, for instance, may lead policy-makers to more practical decisions. Also, participation in national policy-making may bring members of an elite closer together, and inspire them with a spirit of togetherness within their circle, which may lead them to a new policy stance. Therefore, social networks and interrelationships are important to understand a policy-maker's knowledge, beliefs and behaviour. 'Differences in the way in which organizations are structured, as well as in the positions people oc- 
cupy within them, affect the flow of information, constraining not only the amount but the specific content of information that people receive' (Trotter 1999, p. 2).

\subsection{Performance of Manufacturing In- dustry}

Figure 1 compares manufacturing value added in Indonesia and in Nigeria. Starting from a similar position in the 1960s, the value added of manufacturing in Indonesia in 2005 was more than fifteen times higher than in Nigeria. In the period 19611970, growth of Indonesia's manufacturing sector was less than 5 percent annually. This was much lower than in Nigeria, which averaged almost 15 percent annually in the same period. However, during the period 1971-1980, after macroeconomic stability was restored, manufacturing in Indonesia grew more than 14 percent annually. This was higher than the growth rate of manufacturing in Nigeria, which slowed down to 11 percent annually in the same period.

Moreover, from the 1980s, manufacturing in Nigeria was not progressing. The rate of growth in manufacturing from 1981 to 1990 was only about 3 percent. In the 1991-2000 period, manufacturing in the country experience negative average annual growth. Decreasing capacity utilization, from 70 percent in 1980 to 40 percent in 1990 and 29.3 percent in 1995 (see Ukoha 2000, p. 129), contributed to the low growth of manufacturing in Nigeria. Ukwu (1994, p. 440) also notes that in the 1980 s, many establishments closed down because they were unable to pay more for their imported materials or to find new sources internally, while those able to survive had to reduce output and cut back on the number of employees. In contrast to the situation in Nigeria, Indonesia's manufacturing sector grew robustly, more than 11 percent annually, from the mid-1980s.

The contribution of manufacturing in the two economies also shows clear differences (see Figure 2). The contribution of manufacturing to Indonesia's GDP grew from 10 percent in 1975 to 25 percent in 2000 , while the contribution of agriculture declined from 56 percent to 17 percent. In Nigeria, the contribution of manufacturing to GDP grew from 4 percent in 1975 to 10 percent in 1983.
However, it then constantly contracted, and contributed only 4 percent to GDP in 2000. Meanwhile, manufacturing in Indonesia surpassed the contribution of agriculture since 1989, while in Nigeria the manufacturing sector still lagged far behind agriculture.

In terms of exports, differences in manufacturing performance between the two countries are also obvious. In the period of the 1970 s to the 1990s, manufacturing exports in Nigeria constituted less than one percent of total merchandise exports. In Indonesia, the contribution of manufacturing to total merchandise exports rose from 1.2 percent in 1970 to 35 percent in 1990 and 57.1 percent in 2000 (World Bank 2007b). Since 1991 the value added of manufacturing also contributed the largest share to GDP. In sum, in Indonesia, manufacturing grew from scratch to be the main engine of growth and exports, while in Nigeria it remained underdeveloped.

In addition, non-durable consumer goods (particularly food, beverages and tobacco, as well as textiles and apparel continued to dominate Nigerian manufacturing in terms of labour and value added (Anyanwu et al. 1997, p. 38). In terms of labour, non-durable consumer goods absorbed 73.6 percent of Nigeria's labour in the manufacturing sector in 1970 and 66.5 percent in 1985 . This is much higher than for capital goods, which absorbed only 15.1 percent and 22.7 percent of labour in manufacturing in the respective years. Similarly, value added of non-durable consumer goods contributed 84.7 percent and 67.4 percent to total manufacturing value added in 1970 and 1985 respectively (Anyanwu et al. 1997, p. 38). In Indonesia, the share of value added of non-durable consumer goods dropped from 80.8 percent in 1971 to 47.6 percent in 1980; meanwhile, value added of consumer durables, intermediate and capital goods increased from 19.2 percent to 52.4 percent in the same period (Thee and Yoshihara 1987, p. 329).

The performance of manufacturing in the two economies corresponds to the development of gross capital formation. Data from the World Bank (2007b) shows that gross capital formation in Indonesia increased rapidly from less than US $\$ 5$ billion in 1973 to US $\$ 70$ billion in 1996. Meanwhile, in Nigeria, gross capital formation only grew from about US $\$ 5$ billion in 1973 to US $\$ 12$ billion in 1981 , and then fell again to US $\$ 5$ billion in 1996. In ad- 


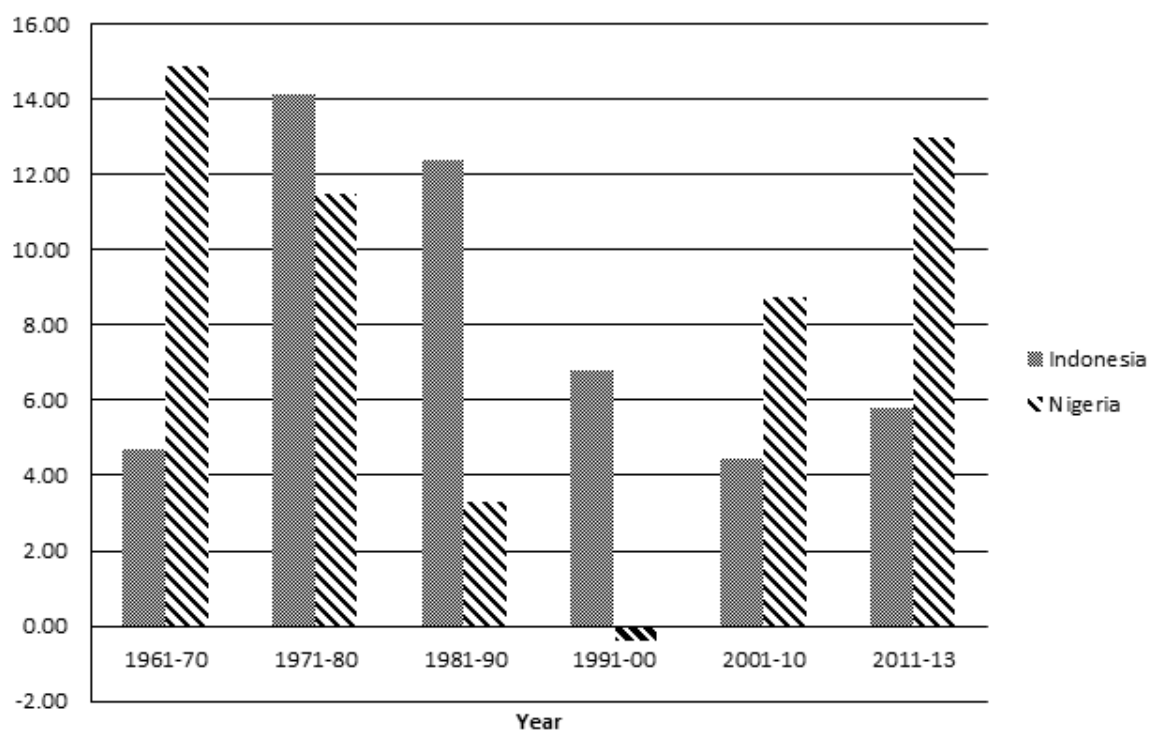

Figure 1: Manufacturing, Value Added Growth (\%)

Source: World Bank (2014); World Bank (2007b) for Nigeria 1961-1980

dition, Figure 3 shows that gross capital formation in Indonesia in 1980s and 1990s, prior to crisis, is more than 25 percent of GDP, compared to that in Nigeria which is about 10 to 15 percent lower.

In term of openness, Table 1 shows that, since the 1980 s, the average rate of tariffs in Indonesia decreased substantially. In 1984, the average applied tariff rate in Indonesia was 37 percent. This decreased to 25.2 percent in 1989 and 19.4 percent in 1993. In Nigeria, however, the average applied tariff rate remained high, more than 30 percent, during the period of liberalization in the second half of the 1980s.

Table 2 shows that capital expenditure allocated to the manufacturing sector as a proportion of total capital expenditure was much lower in Indonesia than in Nigeria. Even though it fluctuated, the participation of the Indonesian government in industry was relatively low. In the First Five-Year Development Plan, 1969-1974, the Indonesian government allocated 1.5 percent of capital expenditure to industrial development. During the oil boom in the 1970s, which increased government revenue, capital expenditure to industry also increased, reaching more than 7.5 percent. With decreasing oil prices in the world market and changing industrial policies, the proportion of capital expenditure to industry decreased. In Nigeria, by contrast, capital expenditure allocated to industry was relatively high.
In the Second National Development Plan (19701974), the figure was only 5.7 percent. However, during the oil booms in 1975-1985, it increased to more than 11 percent of total capital expenditure. Moreover, after the adoption of the structural adjustment program (1986), industry's share of capital expenditure reached 25.3 percent in 1987 (Ekpo 1996, p. 237).

In Nigeria, the share of public investment in GDP in the 1980s was even higher than in the 1970s, while private investment nearly collapsed (Lewis 2007, p. 190). According to Lewis, in the 1970s public investment averaged less than 7 percent of Nigeria's GDP, and in the 1980s it reached more than 10 percent; meanwhile private investment dropped from 15.9 percent in the 1970 s to only 5.3 percent in the 1980s. Moreover, in 1988, public investment reached a remarkably high 88.8 percent of total investment in the country (Anyanwu et al. 1997). This contrasts with the situation in Indonesia, where private investment increased steadily from 14.5 percent of GDP in the 1970s to 17.9 percent in the 1980s and 20.9 percent in the 1990s (Lewis 2007, p. 190).

The growing participation of the private and the foreign sectors in Indonesia can also be seen in the changing structure of credit. After the financial liberalization of 1988, the share of credit from government banks decreased steadily, while the 


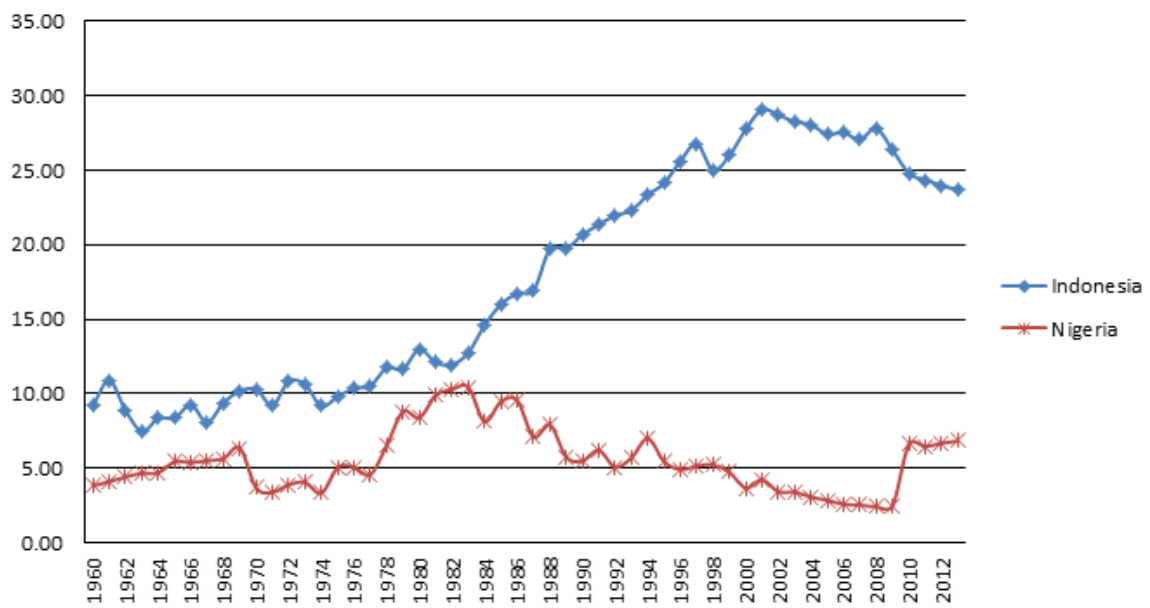

Figure 2: Manufacturing, Value Added (\% of GDP)

Source: World Bank (2014) and World Bank (2007b) for Nigeria 1960-1980

Table 1: Average Applied Tariff Rate (Unweighted in \%)

\begin{tabular}{ccc}
\hline Year & Nigeria & Indonesia \\
\hline 1984 & 35.0 & 37.0 \\
1989 & 35.6 & 25.2 \\
1993 & 32.8 & 19.4 \\
1999 & 24.6 & 9.9 \\
2003 & 24.7 & 6.0 \\
2006 & 11.7 & 6.0 \\
\hline \multicolumn{3}{l}{ Source: World Bank (2007a) }
\end{tabular}

share of private and foreign banks increased substantially. The share of credit from government banks in the Indonesian economy decreased from 67.35 percent in $1988 / 89$ to only 35.65 percent in 1997/98; meanwhile, credit from domestic private and foreign banks increased over the same period from 28.2 and 4.4 percent to 53.5 and 10.8 percent respectively (Nota Keuangan and RAPBN $1998 / 1999$, p. 286). The increasing role of domestic private banks and foreign banks is also clear in the industrial sector (Table 3). Even though government banks remained important in providing credit to industry, the share of credit from domestic private and foreign banks increased substantially, from 16.6 and 5.2 percent respectively in 1988/89 to 37.8 and 23.4 percent in $1997 / 98$.

This section has shown the differential performance of manufacturing in Indonesia and Nigeria, particularly since the 1980s. Indonesia was more open to the world market economy than Nigeria, as seen in the inflows of FDI and in the tariff rates. In addition, the government's role in indus- try decreased steadily in Indonesia, while it did not decrease in Nigeria. There was a clear trend for higher private and foreign participation in Indonesia, while in Nigeria the government's role in the economy remained strong.

\subsection{Industrialization Policies}

Industrialization has been regarded by many development economists as a major path to achieving a faster rate of economic growth and a higher standard of living (Ghatak 2003). Therefore, it is not surprising that policy-makers in newly-independent countries considered industrialization to be the best and fastest way to develop their country. This section shows how industrialization and FDI policies in Nigeria and Indonesia changed over time, due to both internal and external factors. In Indonesia, government intervention in industrialization rose or fell following changes in oil prices and changes in cabinet ministers. However, there was a clear trend for Indonesia's industrial policy 


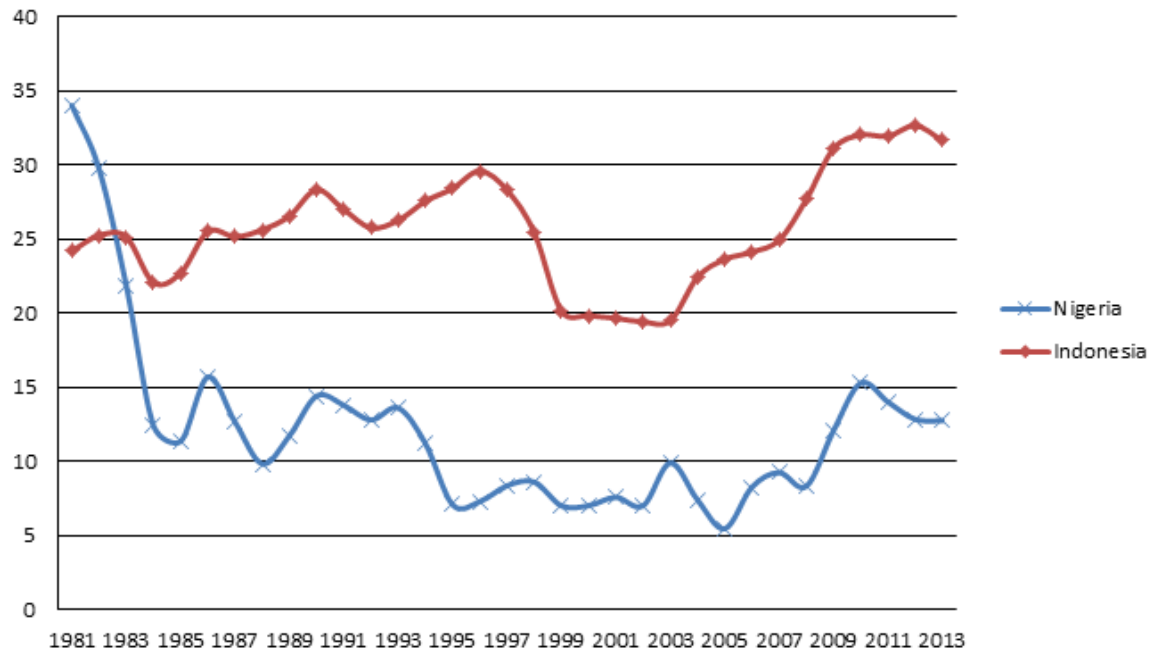

Figure 3: Gross Capital Formation (\% GDP)

Source: World Bank (2014)

Table 2: Proportion of Government Capital Expenditure Allocated to Industrial Development (Annual Average in \%)

\begin{tabular}{cccc}
\hline \multicolumn{2}{c}{ Indonesia } & \multicolumn{2}{c}{ Nigeria } \\
\hline $1969-1974$ & $1.5^{\star}$ & $1970-1974$ & 5.7 \\
$1974-1979$ & $4.72^{*}$ & $1975-1980$ & 12.7 \\
$1979-1984$ & 7.65 & $1981-1985$ & 11.1 \\
$1984-1989$ & 5.27 & $1986-1990$ & 13.4 \\
$1989-1994$ & 5.22 & & \\
\hline Note: * Includes the mining industry. \\
Source: Data for Indonesia based on Nota \\
Keuangan dan RAPBN 1998/1999 \\
(p. 127). Data for Nigeria based on \\
Federal Ministry of Industry and \\
Technology (1992, p. 47) and Ekpo \\
(1996, p. 237)
\end{tabular}

through trade and investment liberalization. Nigeria, by contrast, had only begun to liberalize its economy in the mid-1980s. Moreover, during the liberalization period in the 1980s, there was still a reluctance to liberalize Nigeria's economy and reduce government intervention remained strong.

\subsubsection{Industrialization Policy in Nigeria}

In the early independence period, Nigeria's federal government continued the colonial policies of Britain to attract foreign investment to the country (Ukwu 1994, p. 435). The Industrial Development (Income Tax Relief) Act of 1958, the Industrial Development (Import Duties Relief) Act of 1957, the Customs Duties (Dumped and Subsidized Goods)
Act of 1958, the Customs (Drawback) Regulations of 1959, and the Income Tax (Amendment) Act of 1959 offered a wide range of incentives for foreign investors, such as tax holidays and a more competitive business environment (Enuenwosu and $\mathrm{Ne}$ media 1980, pp. 5-6). During this early independence period, however, the Nigerian government had also started to turn to import-substituting industries and was convinced of the need to have an independent economy. The vigorous importsubstitution strategy was meant to reduce overdependence on imported products and to save foreign exchange reserves (Anyanwu et al. 1997, p. 36).

In addition, the call for a broad-based nationalist movement was growing. Chief Obafemi Awolowo, 
Table 3: Credit to the Manufacturing Sector in Indonesia by Source (Billions of Rupiah)

\begin{tabular}{lccccc}
\hline Source of Credit & $1988 / 89$ & $1989 / 90$ & $1990 / 91$ & $1991 / 92$ & $1992 / 93$ \\
\hline \hline Government Banks & 12259 & 16198 & 21544 & 22420 & 27615 \\
& $(78.17)$ & $(72.15)$ & $(68.80)$ & $(63.31)$ & $(63.52)$ \\
Private Banks & 2602 & 4385 & 6706 & 8473 & 10325 \\
& $(16.59)$ & $(19.53)$ & $(21.42)$ & $(23.93)$ & $(23.75)$ \\
Foreign Banks & 822 & 1866 & 3063 & 4518 & 5533 \\
& $(5.24)$ & $(8.31)$ & $(9.78)$ & $(12.76)$ & $(12.73)$ \\
Total & 15683 & 22449 & 31313 & 35411 & 43473 \\
& $(100 \%)$ & $(100 \%)$ & $(100 \%)$ & $(100 \%)$ & $(100 \%)$ \\
& & & & & \\
\hline Source of Credit & $1993 / 94$ & $1994 / 95$ & $1995 / 96$ & $1996 / 97$ & $1997 / 98$ \\
\hline \hline Government Banks & 28452 & 30059 & 32846 & 34807 & 41983 \\
Private Banks & $(53.20)$ & $(47.74)$ & $(44.98)$ & $(42.85)$ & $(38.86)$ \\
& 15696 & 20954 & 24930 & 30212 & 40816 \\
Foreign Banks & $(29.35)$ & $(33.28)$ & $(34.14)$ & $(37.19)$ & $(37.78)$ \\
& 9335 & 11954 & 15247 & 16215 & 25224 \\
Total & $(17.45)$ & $(18.98)$ & $(20.88)$ & $(19.96)$ & $(23.35)$ \\
& 53483 & 62967 & 73023 & 81234 & 108023 \\
\hline
\end{tabular}

Note: Number in parentheses is the percentage of credit received by industry. Source: Calculated from Nota Keuangan dan RAPBN 1998/1999 (p. 286)

leader of the opposition in the Federal House of Representatives in the First Republic, for instance, 'urged Nigeria to follow the example of India, Burma, Ceylon, Thailand, and Indonesia which had nationalized the Dutch companies and yet found that foreign investors "flock" to them' (Enuenwosu and Nemedia 1980, p. 7). Considering the constraints in human and material resources, the government decided not to opt for nationalization. However, nationalization later evolved into 'indigenization', or 'Nigerianization' of foreign companies.

During the oil boom in the 1970s Nigeria adopted nationalist policies toward foreign investment. In the Second National Development Plan (19701974), the government had emphasized the need for the economy to be directed by Nigerians themselves. A desire to end foreign domination of the Nigerian economy was the main factor in the drive toward nationalist policies. In 1970, for instance, foreigners dominated 57.3 percent of manufacturing and processing industries, 100 percent of mining and quarrying industries, and 91.3 percent of building and construction industries ( Anyanwu et al. 1997, p. 39). The Second National Development Plan stated that:

The uncompromising objective of rising economic prosperity in Nigeria is the economic independence of the nation and the defeat of neo- colonialist forces in Africa. [...] Nigeria will [...] quicken its pace of development through the use of her own resources instead of relying unduly on external aid. This is the only way for an aspiring nation like Nigeria to develop at a rapid rate and in the right direction. (Enuenwosu and Nemedia 1980, p. 8)

As a result, the government launched the Nigerian Enterprises Promotion Decree (NEPD) No. 5 of 1972, also known as the Indigenization Decree, to work toward the goal of increasing indigenous ownership. Joseph Adetoro, Minister of Industry (1972-1974), who is also known as 'Mr Indigenization', noted:

With it the nation took the very bold but inevitable step to lay the foundation of industrialization and to remove by stages the already stifling dependence on foreign expertise, foreign raw materials, foreign organizational values and foreign control of our nation's economic life. (Federal Ministry of Industry and Technology 1992, p. 275)

The decree provided guidelines for investment and dictated the transfer of equity ownership from foreign investors to domestic actors. Schedule 1 of the decree reserved an exclusive monopoly for Nigerians in advertising, gambling, electronics manufacturing, bread and candle making, road transport, laundering, municipal bus and taxi ser- 
vices, media, and retail (Beveridge 1991, p. 309). Schedule 2 of the decree restricted foreign participation to 60 percent in domestic air traffic, shipping, construction, wholesale distribution, travel agencies, basic commodity production, and lowtechnology manufactured goods, such as furniture, cement, matches, and household chemicals, if the enterprise's capital was more than 200,000 naira. If the size of the enterprise was less than that, foreign participation was fully banned (Beveridge 1991, p. 309).

Increasing government revenue because of the oil boom also led the Nigerian government to increase its involvement in the manufacturing sector. Thus, a public-led industrialization strategy was added, while the private sector was neglected (Federal Ministry of Industry and Technology 1992, pp. 512). With the belief that development of manufacturing is a major instrument for rapid growth and selfsufficiency, huge resources were channelled to industry. '[Direct government investment in manufacturing allowed the government to exercise almost a complete monopoly in the following sub-sectors: basic steel production, petroleum refining, petrochemicals, liquefied natural gas, edible salt, flatsteel plants, machine tools, pulp and paper (basic), yeast and alcohol, and fertilizer (nitrogenous and phosphatic]' (Anyanwu et al. 1997, p. 36).

Five years later, in 1977, Obasanjo's administration applied a second round of indigenization. It expanded the 1972 Indigenization Decree, by adding film distribution, radio and television operation, newspapers and hairdressing to Schedule 1 , and reclassifying some sub-sectors which previously had fallen under Schedule 2, such as travel agencies and wholesale, to Schedule 1. For activities falling under Schedule 2, the requirement of 40 percent Nigerian participation was increased to 60 percent. In addition, Schedule 3 mandated a 40 percent Nigerian participation for technology-intensive activities, such as manufacturing of chemicals, drugs, pottery and metal manufacturing, and also the hotel industry and oilservicing companies (Beveridge 1991, pp. 3156). Babangida, a member of the Supreme Military Council (SMC) at the time, recalls that there was no disagreement in the SMC on the necessity for the government to intervene in the economy (Interview 19/08/2009). This indicates how strongly policy-makers in Nigeria at that time preferred nationalism over liberal economic policies.
For Nigeria, the recession in the world economy and the drop in oil prices in the world market in the 1980 s led to a change in the government's policy on manufacturing. In 1981, the Nigerian government relaxed the Indigenization Decree by reclassifying a number of activities from Schedule 2 to Schedule 3 of the 1977 NEPD (Beveridge 1991, p. 320; Metz 1991). When oil prices continued to decline, in 1985 the 'government selectively relaxed the Indigenization Decree to encourage foreign investment in neglected areas, such as large-scale agribusiness and manufacturing that used local resources' (Metz 1991).

The structural adjustment program adopted in July 1986 also emphasized an export-promotion strategy, to invite more private participation and foreign investment. In 1987, the NEPD allowed enterprises to increase capital by 'the issue of nonvoting shares from indigenous or foreign sources in spite of the provisions of the 1977 NEPD' (Beveridge 1991, p. 320). According to Metz (1991), foreign investors were allowed to increase their share of ownership in a number of other sectors in 1988. Biersteker and Lewis (1997, p. 313) note that in 1988 a new industrial policy was designed to deregulate and liberalize the investment environment, and the Industrial Development Coordinating Committee was established to attract more foreign investment. Approval and screening procedures for the establishment of new enterprises were also streamlined (Beveridge 1991, p. 321). The Indigenization Decree was significantly relaxed in 1989 , following an agreement between Nigeria and the World Bank on economic reform. The restrictions in Schedules 2 and 3 were repealed, and only 40 activities in Schedule 1 were left (Beveridge 1991, p. 321).

The liberalization measures in Nigeria, however, were half-hearted. For instance, Bunu Sherif Musa, Minister of Industry (August 1985 to September 1986), stated that during the structural adjustment program period, he was impressed by three of the policies for industrialization, namely the policy on local sourcing of raw materials, the policy on indigenization of key positions in strategic industries, and the policy on dialogue with the organized private sector (Federal Ministry of Industry and Technology 1992, pp. 276-77). Unlike Indonesia, which eliminated the Ministry for the Utilization of Domestic Components from the fifth Development Cabinet (1988-1993), Nigeria's industrial policy dur- 
ing the structural adjustment program made local sourcing of raw materials a main strategy for industrialization.

Bunu Sherif Musa clearly expressed his negative sentiments toward foreign participation in the economy:

However, amongst those entrepreneurs [...], some came in with the intention of really making Nigeria attain greater heights, but many others came in to exploit the country. Many entrepreneurs placed non-indigenous or non-Nigerians in key positions in order to conceal the secrets of business. (Federal Ministry of Industry and Technology 1992, p. 277)

Nigeria's new industrialization policy was a response to the World Bank's criticism of Nigeria's manufacturing development, particularly that there was too much resource allocation to large, capitalintensive, mport-substituting industries, such as steel, pulp and paper, and petrochemicals (Ukwu 1994, p. 440). The new industrial policy of 1989 limited the role of the public sector to:

- Encouraging private-sector participation by privatizing government holdings in industry.

- Playing a catalytic role in establishing new core industries.

- Improving the regulatory environment.

- Improving the country's investment climate.

- Establishing a clear set of industrial priorities.

- Harmonizing industrial policies at federal, state and local levels of government (Federal Ministry of Industry and Technology 1992, p. 64).

However, the achievements of the SAP and the 1989 industrial policy were disappointing. Instead of increasing private investment, the share of public investment in GDP in the 1980s increased.

\subsubsection{Industrialization Policy in Indonesia}

In Indonesia, industrialization started with nationalist-protectionist measures. In 1951, Sumitro Djojohadikusumo, Minister of Trade and Industry, introduced the Economic Urgency Plan (Rencana Urgensi Perekonomian), also known as the Industrial Urgency Plan or the Sumitro Plan. The plan emphasized the need for government to take control and ownership of the economy, particularly key industries. There was also the Benteng program to protect and increase the role of indigenous people or pribumi (Chalmers 1990, p. 6). Moreover, in the late 1950s many foreign companies were nationalized.

However, Indonesia's industrialization policy changed substantially after the collapse of the Sukarno administration. Challenged with economic deterioration and insufficient government revenue, Indonesia at the beginning of Suharto's New Order adopted a liberal economic policy. In terms of investment policy, for instance, Mohammad Sadli, chairman of the Technical Team for Investment (Tim Teknis Penanaman Modal) from 1967 to 1973 , stated that the New Order government considered FDI to be crucial, since the country lacked domestic savings for capital investment. At this time, foreign loans were the main source of funds to achieve macroeconomic stability and to rehabilitate the economy (Sadli 1993, p. 43).

The government launched a new Foreign Investment Law in 1967. The government also issued a guarantee that foreign firms would not be nationalized. The government also returned many foreign firms, which had been nationalized during the Sukarno period, to their former owners, except the Dutch owners whose firms had been nationalized in 1958. For domestic investors, the government also launched the Domestic Investment Law in 1968. Together, these two investment laws provided quite a strong legal basis for investors to become involved in the Indonesian economy. The acts provided for a wide range of incentives, such as tax holidays and exemption of import duties, as well as exemption of sales taxes on capital goods (Pangestu 1996, p. 152).

At the time, Sadli observed that there was not much competition from other countries to attract FDI. There was also no requirement for foreign investors to have domestic partners to invest in Indonesia, while other countries such as Thailand and the Philippines required such a partnership (Sadli 1993, p. 43). In addition, tax holidays, opportunities to exploit natural resources, and abolition of foreign-exchange controls made Indonesia an attractive destination for foreign investment (Sadli 1993, p. 43).

Similar to Nigeria when the oil windfall started in the early 1970s, Indonesia's industrialization strat- 
egy changed substantially. 'Industrialization was accelerated because of a combination of importsubstitution policies, regulation of investment and increasing state ownership' (Pangestu 1996, p. 118). Pangestu also noted that interventions in industry were motivated not only by the aim to develop infant industries, but also to increase value added, to increase industrial linkages, and to deepen Indonesia's industrial structure.

In January 1974, the government issued policy changes in foreign direct investment. According to Prawiro (1998b, p. 222): (1) every foreign investment had to be in the form of a joint venture with a pribumi (domestic indigenous) partner; (2) foreign investors had to shift 51 percent of their ownership to their Indonesian partner within ten years; (3) if the partner was not a pribumi, this 51 percent ownership had to be sold through stock markets, with at least 50 percent to be sold to pribumi; (4) to protect existing investments, many sectors were closed to new investment; and (5) state-owned banks were instructed to limit the provision of credit to pribumi only. At the end of 1973, Bank Indonesia introduced two new schemes to provide credit to indigenous small-scale enterprises, namely small investment credit (KIK, Kredit Investasi Kecil) and credit for permanent working capital (KMKP, Kredit Modal Kerja Permanen) (Poot, Kuyvenhoven, and Jansen 1990, p. 211).

The spirit of nationalism was very intense during this period. Besides increasing government revenue from oil money, the rise of nationalist sentiment was also driven by dissatisfaction among the pribumi group, and ultimately resulted in the January 1974 riots. The tragedy, usually referred to as the Malari Incident, or simply Malari (Malapetaka Januari), was a series of large-scale anti-Japanese riots. These riots happened when Japanese Prime Minister Kakuei Tanaka visited Indonesia in January 1974. People were dissatisfied because of the Japanese and ethnic Chinese domination over the economy. In the riots, hundreds of cars were burned, shops looted, and a day later a dozen looters were killed (Robison 1986, pp. 1648; Schwarz 2004, p. 34). The changes in government policy were mainly a response to the pressure of the Malari Incident.

Oil money also moved the Indonesian economy toward nationalist policies because it strengthened the position of Pertamina, Indonesia's state oil company. General Ibnu Sutowo, president-director of Pertamina since 1957, was well known as an aggressive state entrepreneur (Lewis 2007, p. 103; Prawiro 1998b, p. 141). With the first oil windfall, and given its relative autonomy from government control, Pertamina expanded investment into many economic sectors, and also to non-economic ventures. Rather than limiting its investments to oilrelated activities, such as petroleum exploration, production, refining and marketing, Pertamina also became involved in steel production, insurance, hospital, air services, telecommunications, rice production, frozen foods and tourism (Lewis 2007, p. 104; Prawiro 1998b, pp. 141-2).

After the second oil windfall in 1979, in the wake of the Iranian revolution and the Iran-Iraq war (19801988), the technicians in the government, led by Habibie, who were in favour of technological development and promotion of large-scale industry, put forward their nationalist projects. As noted by Lewis (2007, p. 109), the government spent more than US $\$ 19$ billion to expand the steel and LNG industries, together with electricity generation, refining, mining, aluminium, petrochemicals, telecommunications, pulp and paper, fertilizers, and cement. In addition, 'Policies for licensing, contracting, credit, and procurement were nominally intended to favour small and medium firms and to foster pribumi enterprise. [... ] High-tariff and nontariff barriers were intended to insulate importsubstitution activities' (Lewis 2007, p. 109). Lewis also noted that the oil windfall also provided the opportunity to increase popular subsidies, the defence budget, public sector salaries, funding for military-controlled businesses, and patronage.

The State Secretariat (Sekretariat Negara, Setneg), which had the authority to tender and implement projects, played a crucial role in channelling the extra resources. Unfortunately, the resources were channelled to patrons such as senior military officers, ethnic Chinese business associates, and the president's family (Lewis 2007, p. 110). Suharto's family, for instance, hijacked protectionist policies by their rent-seeking activities, which included acquiring privileges in public utilities projects, such as in transportation, telecommunications and the state electricity company (PLN) (Robison and Hadiz 2004, pp. 77-80).

When the economy slowed down because of decreasing oil prices, the Indonesian government 
started a series of deregulation measures in 1983. Kuncoro and Resosudarmo (2006, p. 346) view this deregulation as a voluntary structural adjustment program, with the main goal being to develop and to diversify non-oil sectors of the economy, particularly manufacturing and agriculture. An immediate response was to devalue the rupiah in order to boost export competitiveness, and to reduce food and fuel subsidies (Lewis 2007, p. 113). The taxation system was simplified to earn more revenue from the non-oil sectors, while a valueadded tax (VAT) was also introduced (Lewis 2007, p. 113; Prawiro 1998b, pp. 334-6). In trade, the government simplified export/import approval procedures, gave exporters greater freedom in the use of their export proceeds, provided subsidized export credit, and reduced import tariffs significantly (Kuncoro and Resosudarmo 2006, p. 346). The national customs service was suspended and their operations taken over by the Société General de Surveillance (SGS), a Swiss-based foreign contractor (Lewis 2007, p. 113; Kuncoro and Resosudarmo 2006, p. 346).

In investment, the procedures for approval of foreign investments were simplified by reducing the number of required documents from 26 to 13 , which cut processing time from more than six months to less than two months (Kuncoro and Resosudarmo 2006, p. 346). In May 1986, new investment policies were introduced: (1) foreign ownership was allowed up to 95 percent; (2) wider financial access for joint-venture investment; (3) investment licenses could be granted for up to 30 years; and (4) no VAT on imported capital (Prawiro 1998b, p. 384). In 1989 the Negative Investment List (DNI) replaced the Investment Priority List (DSP), which meant that investors could be involved in more than one economic sector (Prawiro 1998b, p. 385).

In the financial sector, the credit ceiling was eliminated for every bank, interest rates were liberalized, and taxes on interest, dividends, and royalties for deposits in foreign currency in stateowned banks were eliminated (Lewis 2007, p. 113; Prawiro 1998b, p. 316). To ease possible liquidity problems that might be triggered by the financial liberalization, the Indonesian government issued Indonesian Treasury certificates (Sertifikat Bank Indonesia, SBI), a discount window, ${ }^{2}$ and promis-

\footnotetext{
${ }^{2}$ This is a monetary instrument that allows eligible institu-
}

sory notes (Surat Berharga Pasar Uang, or SBPU) in 1984 and 1985 (Prawiro 1998b, p. 317).

Further financial deregulation took place in 1988. The government launched the 'October 1988 package' (Paket Oktober 1988, Pakto), which was designed to further develop the banking sector. Foreign banks were allowed to open branches in six major cities outside of Jakarta; the reserve requirement to establish a domestic bank was reduced from 15 percent to 2 percent; the monopoly on deposits of state-owned enterprises by state-owned banks was reduced; and a longer term for monetary instruments was allowed (Prawiro 1998b, pp. 342-3). In addition, the stock market was liberalized by easing requirements for listing equities and allowing a wider range of brokerage activities; and regulations on venture capital, insurance and nonbank financial activities were eased (Lewis 2007, p. 116).

The high costs of the government's importsubstitution strategy were increasingly questioned. Several big projects were cancelled or postponed due to the austerity measures. Hartarto, Minister of Industry (1983-1993), also came out in favour of deregulation measures (Pangestu 1996, p. 126). Moreover, Pangestu notes that the 1988 cabinet was strongly liberal because the Ministry of Industry (in spite of their usual interventionist preference) supported the lobby for the deregulation policies advocated by the economist-technocrats in the cabinet. In addition, the Ministry for the Utilization of Domestic Components, which had increased protective measures in the previous period, was abolished (Pangestu 1996, p. 127).

\subsection{Biographies of Policy-Makers}

\subsubsection{Indonesian Policy-Makers}

After the collapse of the Indonesian economy in mid-1965, the New Order government was installed in early 1966. A group of US-trained economists and one Canadian-trained economist (Professor Subroto) from the Faculty of Economics, University of Indonesia, helped to design

tions to borrow from the central bank, usually on a short-term basis, to meet temporary shortages of liquidity caused by internal or external disruptions. 
and implement economic stabilization policies at the on set of the Suharto regime in 1966. They were proponents of sound market-oriented policies (Kuncoro and Resosudarmo 2006, p. 343), but they were not committed to laissez-faire economics (Basri and Hill 2004, p. 644). During the stabilization period (1966-1972), the role of these economists was quite fundamental in designing and implementing economic policies. Important to note here is the role of Mohammad Sadli, who was assigned to promoting investment after the enactment of the Foreign and Domestic Investment Laws in 1967 and 1968 respectively. He was appointed the first chairman of the Technical Team for Investment (Sadli 1993, p. 41).

Besides Sadli, another figure who played an important role in designing FDI policies is Abdoel Raoef Soehoed. When the New Order started, Soehoed was asked by Sanusi Hardjadinata, Senior Minister of Industry and Development, to help him as the minister's advisor. In that capacity he was involved in the return of foreign companies that had been nationalized during the 1950s, such as Goodyear to its American owners and Heineken to its Dutch owners. He was also appointed a member of the Technical Team for Investment, which became the Investment Coordinating Board (Badan Koordinasi Penanaman Modal, BKPM). Under Sadli's coordination, Soehoed was in charge of foreign capital investment and Sri Pamungkas of domestic capital investment (Soehoed 2001, p. 203). The Foreign Investment Law was then enacted in 1967 and became an important measure driving Indonesia to economic liberalization. When the BKPM was established, Soehoed was appointed deputy director. The enactment of the Foreign Investment Law fundamentally reversed the anti-foreign paradigm of the previous regime.

Even though Indonesia had embarked on an opendoor policy, the government was very active in promoting industrialization. This is not surprising if we look at who was in charge of the cabinet. An important person behind industrialization in Indonesia was Sumitro Djojohadikusumo. Born on 29 May 1917 at Kebumen, Central Java, Dr. Sumitro Djojohadikusumo was one of the principal architects of Indonesia's post-colonial economy. He had held several important economic portfolios since Indonesian independence. During Sukarno's period, Sumitro was three times cabinet minister. In the Natsir cabinet (September 1950 to April 1951), he was Minister of Trade and Industry. He was then appointed Minister of Finance in the Wilopo cabinet (April 1952 to July 1953) and the Burhanudin Harahap cabinet (August 1955 to March 1956).

Because of his involvement in the Revolutionary Government of the Republic of Indonesia (Pemerintah Revolusioner Republik Indonesia) (rebel movement, he stayed out of the country from 1958 to 1967. During that period, he became an economic advisor in Malaysia, Thailand, Hong Kong, France and Switzerland. He only returned to Indonesia just after Sukarno stepped down and the New Order was installed. Suharto immediately appointed him a member of the Economic Advisory Team for the President. He then became Minister of Trade in the first Development Cabinet (19681973) and Minister of State for Research in the second Development Cabinet (1973-1978).

Sumitro's important role in shaping industrialization policy in Indonesia is related to the fact that there were very few Indonesian economists in the country in the early independence period. According to Thee (2010, p. 38), 'In the early 1950s there were only two qualified economists, Muhammad Hatta and Sumitro Djojohadikusumo, who had both studied at the Netherlands School of Economics (Nederlandse Economische Hogeschool) in Rotterdam'. Other economic policy-makers at the time, including Sjafruddin Prawiranegara, Djuanda Kartawidjaja, Yusuf Wibisono and Ong Eng Die, had no formal training in economics.

Sumitro was a socialist who advocated an active role of the government in the economy. In the early 1950s, he was a proponent of direct investment by the government, to counter the domination of foreign investment (see Thee, 2010, pp. 51-2). In addition, when he was Minister of Trade early in the New Order, he advocated an active role of the government in industry. Ian Chalmers (1996, p. 178), for instance, notes how Sumitro supported protection of the automobile industry in the late 1960s. As Minister of Trade, Sumitro banned the import of luxury cars in 1968 and limited the role of foreign capital through licensing for auto production in 1969, so that local industry could grow, while also saving foreign exchange reserves. Therefore, all automobile assemblers were owned by Indonesians, even though licensed by foreign (particularly Japanese) firms (Thee and Yoshihara 1987, pp. 330-1). Suhadi Mangkusuwondo considered 
Sumitro as someone who was always concerned about the position of domestic producers relative to foreign companies. This was significantly different from his successors at the Ministry of Trade, such as Radius Prawiro, who was more pragmatic (Interview 28/08/2008). Sumitro's socialist-nationalist views seem clearly to be related to his educational background, as seen below.

Having graduated from Senior Civilian School (Hogere Burger School (HBS), the prestigious senior high school in Batavia, Sumitro went to Rotterdam in 1935, where he studied at the Netherlands School of Economics (Netherlands School of Economics) and earned his bachelor's degree in 1937. $\mathrm{He}$ then studied philosophy, French and literature at the Sorbonne in Paris (1937-1938). After this he returned to the Netherlands in 1938 and earned his master's degree at the Netherlands School of Economics in 1940. During his time in Paris, he joined a socialist group and met with André Malraux, Jawaharlal Nehru, Henri Bergson and Henri Cartier-Bresson. At the age of 25 years, Sumitro defended his doctoral thesis, entitled 'Het Volkscredietwezen in de Depressie' (The People's Credit System during the Depression, in 1943. During his university study in the Netherlands, the Nazi oppressors attacked the Netherlands. Sumitro, working in the coal distribution services, took part in helping Dutchmen in hiding by passing on coupons (Cnossen 1995). When he returned to Indonesia in early 1946, Sumitro discarded his noble traditional title of Raden Mas. He joined Sutan Sjahrir in Indonesia's Socialist Party, PSI, whose core support at the time consisted of Indonesian intellectuals.

The role of persons in charge of the Ministry of Industry cannot be neglected. General Mohammad Yusuf, born in Bone Selatan, South Sulawesi, on 23 June 1928, was minister of industry in the first and second Development Cabinets (19681978), and then became an active military officer. He held several military commands during the revolutionary and the Sukarno periods. Together with Amirmachmud and Basuki Rahmat, Yusuf arranged the Surat Perintah Sebelas Maret (Supersemar), which authorized Suharto to take over power from Sukarno and start the New Order. He was the only military officer to occupy an economic post in Suharto's first Development Cabinet (1968-1973). Suharto's choice may have been designed to guarantee the involvement of the military, whereas the other economic posts were dom- inated by FEUI economists. However, Yusuf got along very well with the economists in the cabinet (Interview 29/11/2008). When he was minister of industry, General Yusuf also followed the guidelines of development, which were mainly written by the economists. Trained and raised in the military, Yusuf did not have much experience or vision of how to industrialize Indonesia. However, he could rely on his general secretary, Barli Halim, an FEUI economist who had earned his degree from the University of California, Berkeley (Sumarkidjo 2006, p. 121).

During Yusuf's tenure, the government tried to establish several industries, such as fertilizers, cement and textiles. These were industries that were proposed by the economists, led by Widjojo Nitisastro, to support agricultural development and to meet the demand for domestic clothing. During the early period of the New Order, there was a challenge of high food prices and insufficient domestic food production. To increase production, fertilizers, pesticides and agriculture-supporting machinery were offered to farmers at subsidized prices. To accelerate infrastructure development, such as irrigation, the cement industry was developed. The government also took an active role in meeting social needs, such as demand for clothing and building materials. During this period, besides its opendoor policy, the government was directly involved in industrialization through the development of stateowned enterprises.

In the 1970s, protectionist schemes such as $\mathrm{KIK}$ and $\mathrm{KMKP}^{3}$ were also advocated by the economists, particularly those from the central bank (BI). BI officials, including Rahmat Saleh and Arifin Siregar, were generally close to the FEUI economists, not only professionally but also personally. Interestingly, among the economists' team, these $\mathrm{BI}$ officials had significant differences compared to the other team members, including Widjojo, Ali Wardhana and Sumarlin. In terms of education, they were not trained in the United States. Rahmat Saleh earned his bachelor's degree in economics from FEUI, while Arifin Siregar earned his Master's degree in the Netherlands and his doctor's degree in Germany.

\footnotetext{
${ }^{3}$ At a National Economic Stabilization Board meeting, December 1973, the president approved the initiative of the governor of Bank Indonesia to introduce a special scheme for pribumi entrepreneurs called small investment credit (KIK) and permanent working capital credit (KMKP).
} 
It is interesting that the non-economist Soehoed, Minister of Industry from 1978 to 1983, was widely regarded as a forceful and articulate advocate of the socalled 'structural approach to industrialization', which advocated an active role for the state. During the New Order, Soehoed was associated with the CSIS (Centre of Strategic and International Studies) group, particularly with Sudjono Humardhani and Ali Murtopo, the main rivals of the FEUI economists in economic policy-making. It is true that Soehoed advocated a structural approach in development, such as introducing subcontracting and partnerships (bapak angkat) for smallscale industry in 1981 (Chalmers 1990, p. 13). Soehoed stressed the importance of state-owned enterprises in developing basic industries:

It is evident that within private national enterprises, there are few companies currently able to become a partner of sufficient weight when facing multinational companies - apart from the state-owned enterprises. The size, staffing and 'stature' of the state-owned enterprises, apart from financial support of the government, clearly makes it the only entities that can compete with the multinational corporations today in the development of basic industries. (Soehoed 1982, p. 55)

Soehoed was not against foreign investment, however. He believed foreign investment was needed to solve the problems of insufficient capital and inadequate technology. Increasing foreign investment in the late 1960 s and early 1970 s was partly due to the policy he implemented when he was on the Technical Team for Investment and the Investment Coordinating Board (BKPM). When the 1974 Malari riots occurred, he was deputy chairman of BKPM, and was blamed for the growing foreign investment from Japan that dominated the domestic economy. Soehoed also strongly defended tax holidays for foreign investors, when the government wanted to delete this in 1971 (Soehoed 2001, p. 218). His experience in the private sector, before joining the New Order government, seems to have influenced his ideological stance: the aim of increasing indigenous participation, while recognizing the need for foreign investment. Since 1978, when Soehoed became Minister of Industry, measures to increase private and foreign participation have never been fully abolished.

The process towards liberalization went further with the appointment of the fourth Development
Cabinet in 1983. The new minister of industry, Hartarto Sastrosoenarto, understood that the government could no longer rely on oil money for industrialization. He believed there was an emergency situation that required inviting private participation in industrialization. Therefore, Hartarto said that deregulation was a necessary step to take before the private sector would be willing to step in. According to him, the private sector will step back if there is too much regulation, and therefore it is better not to have too much regulation, which may create a high-cost economy (Interview 28/11/2008).

Even though Hartarto did not get along very well with the FEUI economists, basically there was not much difference in their policy stance, particularly regarding deregulation measures. They agreed on the importance of creating a business climate that was conducive to industrialization. Interestingly, Hartarto was an engineer and a career bureaucrat in the Department of Industry before he occupied the top-level position in the department. $\mathrm{He}$ graduated as a chemical engineer from the University of New South Wales in Sydney, Australia, and has usually been portrayed as an opponent of the economists in policy-making. Hartarto's standpoint of advocating private participation seems to have come from his experience in managing several state-owned enterprises. He got this experience by being a participant in a management training program to fill management positions in nationalized firms in the late 1950s (Interview 28/11/2008).

Finally, I want to highlight the role of Johanes Baptista Sumarlin, minister of finance from 1988 to 1993. Sumarlin, who came from a peasant family in Blitar, was probably the most important person in the mid-1980s in Indonesia's economic liberalization process. During his tenure as Minister of Finance, Indonesia inaugurated a drastic financial liberalization through monetary deregulation on 27 October 1988, known as Pakto 1988, which led to a controversial huge credit expansion. The deregulation facilitated the entry of private and foreign participation in the banking sector. The increasing role of private and foreign banks led to the infusion of more credit for the manufacturing sector and maintained the growth of gross capital formation.

Sumarlin's liberal ideology seems to have come from his education and his experience in managing the Indonesian economy from the beginning of the New Order. He was trained as an economist 
at the Faculty of Economics, University of Indonesia (FEUI) in 1954. His friendship with Widjojo was strengthened at the University of California, Berkeley, where he earned his Master's degree in 1960. He then became a lecturer at FEUI, and subsequently continued his studies at the University of Pittsburgh in Pennsylvania, USA, obtaining his Ph.D. in 1968 with a thesis entitled Some Aspects of Stabilization Policies and Their Institutional Problems: The Indonesian Case 1950-1960. In 1970-1973, Sumarlin was secretary of the monetary board and a deputy on the National Development Planning Board (Bappenas), with responsibility for fiscal and monetary policy. During Suharto's period, his career was very good; he held many ministerial posts, including Vice-Chairman of Bappenas (1973-1982), Minister of the State Apparatus (1973-1983), Minister of Planning and National Development (1983-1988), Chairman of Bappenas (1983-1988), Minister of Education ad interim (1985), and Minister of Finance (1988-1993) (TokohIndonesia.com, 2004).

\subsubsection{Nigerian Policy-Makers}

After independence, Nigeria's economic policy was liberal, allowing full foreign participation in the economy. However, the seed of economic nationalism had already grown during this period, pioneered by Chief Obafemi Awolowo. Awolowo, a Yoruba, was known as a leader of the Action Group, a political party. He also served as premier of the Western Region (1954-1959). After Nigeria's independence, he led the opposition in the government, because his party lost the 1959 federal parliamentary elections. In 1962 he was tried and then jailed until the First Republic collapsed. Therefore, in the early days of independence, Awolowo did not have the opportunity to manage the Nigerian economy. However, when Gowon took power in 1966, Awolowo was released from prison and was invited to join the cabinet as federal commissioner of finance. He remained in this position until 1971, when the Biafran war ended. One of his legacies was his ability to manage Nigeria's finances throughout the costly civil war without borrowing a single kobo from foreign countries (Federal Ministry of Industry and Technology 1992, p. 274). In managing the economy, Awolowo was a typical 'fiscalist' or Keynesian economist, who believed in the use of fiscal policies to promote eco- nomic development (Bamisaye 2002, p. 376). In terms of industrial development, like Sumitro in the 1950s in Indonesia, Awolowo advocated nationalist economic ideas and an active role of the government in the economy.

Awolowo's nationalist sentiments likely came from his experience as an outstanding leader of Nigeria's independence movement. He was born on 6 March 1909 in Ikenne, present-day Ogun State. He was educated at Anglican and Methodist schools in Ikenne and at Baptist Boys' High School in Abeokuta, Western Nigeria. He then attended teachers training courses at Wesley College in Ibadan. In 1939, he studied part-time and earned a bachelor's of commerce in 1944. In June 1940, he was secretary of the Ibadan branch of the Nigerian Youth Movement, and in 1943 he was one of the founders of the Trades Union Congress of Nigeria (Olson and Shadle 1996, p. 89). He then went to London to study law, finishing in 1947. In the early 1950s, Awolowo established the Action Group, a political party that aimed to guarantee freedom for all and that promised a better life for Nigerians. Awolowo believed that to make the country great, Nigeria must first achieve economic freedom; otherwise the economy would fail (Odey 2002 , p. 343). In 1951, he won the regional elections and became chief minister of the Western Region, which was the first self-governing region before Nigerian independence (Olson and Shadle 1996, p. 89). Together with Nnamdi Azikiwe, an Ibo politician, he demanded self-government for Nigerians during the constitutional convention in 1953 (Olson and Shadle 1996).

Another person important for Nigeria's industrialization policy is Philip Asiodu, who was twice permanent secretary of the Federal Ministry of Industry. The first term was from April to June 1965. In this period, as acting permanent secretary, he implemented the separation of industry from the Federal Ministry of Commerce and Industry into the Federal Ministry of Industry. He not only designed the structure of the new ministry, but also identified industrial programs in preparation for the Second National Development Plan (1970-1974) (Federal Ministry of Industry and Technology 1992, p. 281). His next assignment at the Ministry of Industry was following the military coup in January 1966. He was permanent secretary at the ministry from January 1966 to January 1971. In this position he continued to design industrial programs. 
In 1969 at the conference on National Reconstruction and Development in Nigeria, for preparing the Second National Development Plan, Asiodu presented Planning for Further Industrial Development in Nigeria. In this paper, he notes that in the industrial sector, foreign private investment had been dominant, and if the situation continued, it would lead to serious economic and political problems (Asiodu 1969, p. 14). Therefore, he said:

It is imperative that Nigerians own some of the equity of the manufacturing firms and retain some of the profits. Politically the situation will be untenable if within a decade, when industry should be much more important, the bulk of the investments are held by foreigners and largely absentee owners. It is at this initial stage that a policy should be set in the mutual interest of investors and Nigerians allowing the latter to acquire a significant stake. (Asiodu 1969, p. 14)

The desire for greater Nigerian participation in the economy grew stronger in the 1970s. In fact, the goal of economic nationalism was widely shared by most members of Nigeria's policy-makers. In the 1970s, there was almost no resistance from the policy-makers against the strong pressure for indigenization of foreign capital. The economic situation at that time, which was dominated by foreign companies, raised demands for more domestic participation. Therefore, the aspiration for greater participation was accommodated in the Second National Development Plan, and then realized in the 1972 Indigenization Decree.

Philip Asiodu was born in a bureaucratic family. His father was a civil servant in the customs services during the colonial period, and had lived in Lagos since 1921. His parents came from Asaba, an Ibospeaking area that is now the capital of Delta State. Asiodu, however, thougt of himself as a Lagosian since he was born on 26 February 1934 in Lagos, the biggest city in Nigeria. He had lived several years in Calabar, a big city in the east, following his father, who was transferred there. However, when he was ten, his father was transferred back to Lagos. He thus grew up in what was then the capital of Nigeria, until graduating from King's College in 1952 (Interview 08/06/2009). After that he moved to England to pursue his studies at Queen's College, Oxford University, where he read philosophy, politics and economics. Previously he had wanted to study law, because he had an interest in pol- itics and he thought politics would go better with law than with engineering (Interview 08/06/2009). After finishing his MA at Oxford in 1956, he stayed in London for a few years before returning to Nigeria, where he joined the Nigerian civil service. Like Sumitro and Awolowo, Asiodu was trained in Europe, which has a strong socialist tradition. Moreover, his background in philosophy, politics and economics may have persuaded Asiodu to use state power to change established ownership and to further develop Nigeria's manufacturing sector.

The position of Minister of Industry in Nigeria was rarely occupied by technocrats, or even persons with basic training in economics. From 1966 to 1998, there were 18 ministers of industry, but not one was trained as an economist. They mainly came from the military, or from an academic background in engineering or public administration, all of which usually prefer state intervention in the economy. When Babangida introduced the structural adjustment program in 1986, he brought forward a few technocrats with an economics background, such as Chu Okongwu, Kalu Idika Kalu and Olu Falae. However, the position of minister of industry continued to be filled by non-economists. For instance, Bunu Sherif Musa, Minister of Industry in the 1980s, for instance, was trained as an engineer.

Bunu Sheriff Musa was born in Maiduguri on 15 January 1947. He studied at a Qur'anic school for his primary education. He then attended a government secondary school in Maiduguri from 1963 to 1967 . He studied at the Federal School of Science in Lagos from 1967 to 1970, before enrolling at Ahmadu Bello University in Zaria. At that university, he obtained his bachelor's degree in engineering, with a specialization in civil engineering, in 1973. He was among the pioneers of the $\mathrm{Na}$ tional Youth Service Corps $\left(\mathrm{NYSC}^{4}\right.$ ) from 1973 to 1974, and was posted to Lagos (Sheriff, 2004). In 1974 Bunu Sheriff Musa was then posted to the Chad Basin Development Authority (CBDA) as an irrigation engineer. In 1978 he was awarded an overseas scholarship to study irrigation engineer-

\footnotetext{
${ }^{4}$ The NYSC, introduced in 1973, was a program designed for new Nigerian graduates to take part in the development of the country. The new graduates have to serve for one year in a city that is not their city of origin, and are expected to mix with people from other tribes and social origins so that they can bring unity to the country.
} 
ing at the University of Southampton. After obtaining his master's degree there in 1980, he returned to serve at the CBDA, where he was promoted in 1982 to general manager of the Authority (Sheriff 2004). When Babangida came to power in 1985, he appointed Bunu Sheriff Musa Minister of Industry. He helt that position for only one year, but it was during a critical period, when Nigeria adopted the World Bank's structural adjustment program. Bunu Sheriff Musa was also one of the ministers who occupied a position in Babangida's cabinet until the dissolution of the Federal Executive Council in 1993. From the Ministry of Industry, he was deployed to the Ministry of Mines, Power and Steel in 1986, to the Ministry of Aviation in 1989, to the Ministry of Water Resources in 1990, and finally to the Ministry of Labour, Employment and Productivity (Sheriff 2004).

\section{Conclusion}

This paper has discussed the continued economic divergence between Indonesia and Nigeria in the early 1980s. In the 1970s, funded by increasing oil revenues, Indonesia and Nigeria both adopted an import-substitution strategy to develop industry. However, when oil revenue decreased, both countries had to alter their industrialization policies. Indonesian policy-makers adopted a series of liberalization measures for export-oriented industries. These changes not only maintained manufacturing performance, but also increased it. By the end of the 1980s, manufacturing had become the engine of exports of the Indonesian economy. Nigeria, with similar pressure on its balance of payments because of decreasing oil revenue, attempted to liberalize the economy through a structural adjustment program and alter the industrialization strategy to make it more export oriented. However, the structural adjustment was half-hearted. Sudden liberalization and inefficient devaluation put even more pressure on industry, which still very much relied on imported raw materials. In addition, Nigerian economic policy-makers during the period still believed in an active role of government in the economy. Instead of decreasing capital expenditures on industry, for instance, the government opted to increase it.

It is sometimes suggested that government in- tervention was an important factor behind the success of industrialization in Indonesia, and not merely the liberalization measures. This paper shows that there was nevertheless a significant reduction of the Indonesian government's role in the economy. It is not only that government capital expenditure allocated to industry was decreasing, but there was also an increasing role in industrial investment for private and foreign participation.

Although Nigeria's economic problems are sometimes blamed on policy inconsistency as a result of elite fragmentation, on the issue of economic nationalism there was in fact strong and consistent agreement among political elites and technocrats alike. Among the policy-makers, there was a strong desire for national economic independence. There was not much room for liberal economists to influence Nigeria's economic management; the only time they had some room for manoeuvre was during the structural adjustment program, and that lasted less than four years. The nationalist economic views of Nigerian policy-makers contrasted with Indonesian policy-makers, who pragmatically liberalized the economy by relying on the market mechanism.

The educational background of policy-makers is a possible explanation of their ideology. Those who advocated nationalist-protectionist measures were usually those who were trained in Europe or in their home country. A similar phenomenon can be seen in Nigeria; those advocating protectionist measures were mainly educated in the United Kingdom and Nigeria. The 1970s policy-makers in Nigeria, such as Awolowo and Philip Asiodu, were trained in Europe. Europe's strong socialist tradition may have influenced their ideas of nationalism. Moreover, economic conditions at the time, when foreign companies dominated the Nigerian economy, led them to advocate nationalist measures. In the 1980s, there were not many changes in Nigeria's economic policy-makers. They were still fragmented and there were only a handful of trained economists in the economic policy arena. The advocates of economic reform through structural adjustment held posts only at the Ministry of Finance and the Ministry of Planning. The remaining economic policy-makers were not fully convinced by the liberalization agenda. Civil servants, for instance, were quite reluctant to carry out the reforms decided by the minister of finance as well as the president. Moreover, during the structural 
adjustment program, the economists did not stay long enough in the government to manage the reforms.

In Indonesia, by contrast, economic policy-making was controlled by US-trained economists who had been influenced by pragmatic liberal economic thinking. Moreover, not only those who were trained as economists advocated economic liberalization; but those with an engineering background also recognized the important role of private participation. Not only the economists, but the engineers as well, who were usually associated with state intervention in the economy, understood that they could no longer finance the protectionist measures and needed to invite private and foreign participation. This standpoint may have been strengthened by their direct experience with state intervention. For example, they had experienced the deregulation measures implemented in Indonesia in the 1960s and 1970s, such as devaluation, that improved the competitiveness of Indonesian products, and this experience may have made them less resistant to liberalization.

\section{References}

[1] Anyanwu, JC, Oyefusi, A, Oaikhenan, H \& Dimowo, FA 1997. The Structure of The Nigerian Economy (19601997), Joanee Educational Publishers, Onitsha.

[2] Asiodu, PC 1969, 'Planning for Further Industrial Development'. Paper presented at the Conference on National Reconstruction and Development in Nigeria.

[3] Bamisaye, OA 2002, 'Awolowo's Planning Strategies: Their Implications', in Obafemi Awolowo: The End of An Era?, eds OO Oyelaran, T Falola, M Okoye \& A Thompson, Obafemi Awolowo University Press, Ile-lfe.

[4] Basri, C \& Hill, H 2004, 'Ideas, Interests and Oil Prices: The Political Economy of Trade Reform During Soeharto's Indonesia', The World Economy, vol. 27, no. 5, pp 633-55.

[5] Beveridge, FC 1991, 'Taking Control of Foreign Investment: a case study of indigenisastion in Nigeria', The International and Comparative Law Quarterly, vol. 40, no. 2, pp 302-33.

[6] Biersteker, TJ \& Lewis, P 1997, 'The Rise and Fall of Structural Adjustment in Nigeria,' in Transition Without End: Nigerian Politics and Civil Society Under Babanginda, eds L Diamond, A Kirk-Greene \& O Oyediran, Lynne Rienner, Boulder.

[7] Central Bank of Nigeria 1980, Economic and Financial Review.

[8] Chalmers, I 1990, 'Antara Tinggal Landas dan Demokrasi Ekonomi: Pembangunan Kapitalis dan Industri Kendaraan Bermotor', Prisma, vol. 7, pp 3-18.

[9] Chalmers, I 1996, Konglomerasi: Negara dan Modal dalam Industri Ototomotif Indonesia 1950-1985, PT Gramedia Pustaka Utama, Jakarta.
[10] Cnossen, S 1995, 'Laudation in honor of Professor Dr. Sumitro Djojohadikusumo Doctor Honoris Causa'. Paper presented at the Hommage to Prof. Dr. Sumitro Djojohadikusomo Doctor Honoris causa, Rotterdam.

[11] Derlien, HU 1990, 'Continuity and Change in the West German Federal Executive Elite 1949-1984', European Journal of Political Research, vol. 18, pp. 349-72.

[12] Eifert, B, Gelb, A \& Tallroth, NB 2002, The Political Economy of Fiscal Policy and Economic Management in OilExporting Countries, No. 2899, World Bank, Washington DC.

[13] Ekpo, AH 1996, 'Patterns of Public Expenditure in Nigeria: 1960-1992', in Economic Reform and Macroeconomic Management in Nigeria, ed A Ariyo, Ibadan University Press, Ibadan.

[14] Federal Ministry of Industry and Technology 1992, Industrialisation in Nigeria: A Handbook, Sahel Publishing \& Printing, Lagos.

[15] Ghatak, S 2003, Introduction to Development Economics, Routledge, London.

[16] Guiso, L, Sapienza, P \& Zingales, L 2006, 'Does Culture Affect Economic Outcomes?', Journal of Economic Perspectives, vol. 20 , no. 12 , pp. 23-48.

[17] Harrison, LE 2000, 'Culture Matters', The Australian Financial Review, 3 November.

[18] Interview 08/06/2009, Phillip Asiodu, Lagos

[19] Interview 19/08/2009, Ibrahim Badamasi Babangida, Minna.

[20] Kohli, A 2004, State-Directed Development: Political Power and Industrialisation in the Global Periphery, Cambridge University Press, Cambridge.

[21] Kuncoro, A \& Resosudarmo, BP 2006, 'The Political Economy of Indonesian Economic Reforms: 1983-2000', Oxford Development Studies, vol. 34, no. 3, pp. 341-55.

[22] Lall, S 1994, 'The East Asian Miracle: does the bell toll for industrial stategy?', World Development, vol. 22, pp. 64554.

[23] Lewis, P 2007, Growing Apart: Oil, Politics, and Economic Change in Indonesia and Nigeria, University of Michigan Press, Ann Arbor.

[24] Metz, HC (ed.) 1991, Nigeria: A Country Study, Washington, GPO for the Library of Congress.

[25] Odey, JF 2002, 'Towards an Autochthonous Industriazation Policy for Nigeria: Reflection on Awolowo's Thought on Economic Liberation', in Obafemi Awolowo: The End of An Era?, eds OO Oyelaran, T Falola, M Okoye \& A Thompson, Obafemi Awolowo University Press, Ile-lfe.

[26] Olson, JS \& Shadle, R (eds.) 1996, Historical Dictionary of the British Empire, Greenwood Press, Westport.

[27] Osso, N (ed.) 1990, Who's Who in Nigeria, Newswatch Communication, Lagos.

[28] Pangestu, M 1996, Economic Reform, Deregulation and Privatization, Center for Strategic and International Studies, Jakarta.

[29] Parry, G 1969, Political Elites, George Allen and Unwin, London.

[30] Poot, H, Kuyvenhoven, A \& Jansen, J 1990, Industrialisation and Trade in Indonesia, Gadjah Mada University Press, Yogyakarta.

[31] Prawiro, R 1998, Pragmatisme dalam Aksi: Pergulatan Indonesia Membangun Ekonomi, Elex Media Komputindo, Jakarta.

[32] Robison, R 1986, Indonesia: The Rise of Capital, Allen \& Unwin, Sidney.

[33] Robison, R \& Hadiz, VR 2004, Reorganising Power in In- 
donesia: The Politics of Oligarchy in an Age of Markets, Routledge Curzon, New York.

[34] Rock, MT 1999, 'Reassesing the Effectiveness of Industrial Policy in Indonesia: Can the Neoliberals be Wrong?', World Development, vol. 27, pp. 691-704.

[35] Sadli, M 1993, 'Recollections of My Career', Bulletin of Indonesian Economic Studies, vol. 29, no. 1, pp. 35-51.

[36] Sheriff, B 2004, 'Ambassador Bunu Sheriff Musa (OFR)'. Available from: <http://www.kanuri.net/borno_ personalities 2 .php?aID $=179>$. [15 July 2011].

[37] Soehoed, AR 1982, 'Industrial Development during Pelita III', The Indonesian Quarterly, vol. X, no. 4, pp. 39-62.

[38] Soehoed, AR 2001, Menyertai Setengah Abad Perjalanan Republik, Pustaka Sinar Harapan, Jakarta.

[39] Stein, H (ed.) 1995, Asian Industrialization and Africa: Studies in policy Alternatives to Structural Adjustment, St. Martin's Press, New York.

[40] Thee, KW 2010, 'The Debate on Economic Policy in Newly-independent Indonesia between Sjafruddin Prawiranegara and Sumitro Djojohadikusumo', Itenerario, vol. 34 (Special Issue 01), pp. 35-56.

[41] Thee, KW \& Yoshihara, K 1987, 'Foreign and Domestic Capital in Indonesian Industrialization', Southeast Asian Studies, vol. 24, no. 4, pp. 327-49.

[42] Thorbecke, E 1998, 'The Institutional Foundations of Macroeconomic Stability: Indonesia versus Nigeria,' in The Institutional Foundations of East Asian Economic Development, eds Y Hayami \& M. Aoki, Macmillan, Basingstoke.

[43] TokohIndonesia.com. 2004, JB Sumarlin: Mengabdi di Pusat Kebijakan Ekonomi. Avalaible from: <http://www.tokohindonesia.com/ensiklopedi/ $\mathrm{j} / \mathrm{jb}$-sumarlin/index.shtml $>$. [3 April 2008].

[44] Trotter, RT 1999, 'Friends, Relatives, and Relevant Others: Conducting Ethnographic Network Studies', in Mapping Social Networks, Spatial Data \& Hidden Populations, eds JJ Schensul \& MD LeCompte, Alta Mira Press, Walnut Creek.

[45] Ukoha, OO 2000, 'Determinants of Manufacturing Capacity Utilization in Nigeria, 1970-1998', The Nigerian Journal of Economic and Social Studies, vol. 42, no. 2, pp. 12130.

[46] Ukwu, UI 1994, 'Industrialization and Economic Development in Nigeria: The Significance of the Structural Adjustment Programme', The Nigerian Journal of Economic and Social Studies, vol. 36, no. 1,2,3, pp. 434-48.

[47] World Bank 2007a, Trends in Average Applied Tariff Rates in Developing and Industrial Countries, 1981-2007. Available from: <http://siteresources.worldbank.org/ INTRES/Res ources/469232-1107449512766/tar2007. $\mathrm{xls}>$. [4 May 2011].

[48] World Bank 2007b, World Development Indicators (WDI) Online. Available from: <http://publications . worldbank. org/subscriptions/WDI>. [1 April 2008]

[49] World Bank 2014, Data. Available from: <http://data. wor ldbank. org/country>. [22 July 2014].

[50] Ziegler, JN 1995, 'Institutions, Elites, and Technological Change in France and Germany', World Politics, vol. 47, no. 3, pp. 341-72. 